\title{
ANALYSIS OF ECONOMIC EFFICIENCY OF GRAIN PRODUCTION OF MAIN FOOD AND GRAIN-FORAGE CROPS IN THE REGION
}

\author{
Iryna Solovey \\ Department of Accounting and Economical and Legal Support of Agroindustrial Business \\ Ternopil National Economic University \\ 11 Lvivska str., Ternopil, Ukraine, 46020 \\ Iryna_1978@ukr.net
}

\begin{abstract}
The estimation of the economic efficiency of agrarian enterprises is based on the use of the system of interconnected indices of natural and valuable calculation that reflect the effect and influence forms of objective economic laws in material production of agrarian sphere taking into account its peculiarities.

In the process of the study of the economic efficiency of grain production of main food and grain-forage crops in the studied region we have considered a series of main production-financial parameters that are determined by their nature as: a ratio between resources consumption and volume of goods and services, produced of these resources; maximal volume of production of goods and services using the minimal cost of resources; obtaining of the maximal result of limited resources, accessible for a human. The essential increase of grain production and improvement of its economic efficiency is, undoubtedly, the most important task of the state agrarian policy, its solution determines guaranteeing of the effective activity of both grain-production subcomplex and agro-industry in whole and also food safety of the country.

The scientific article presents the analysis of the economic efficiency of grain production on the example of agrarian enterprises of Ternopil region in 2010-2016. The work demonstrates economic-financial results of realization of grain and leguminous crops of the region and also presents production-economic indices of realization of grain of main food and grain-forage crops wheat, corn for grain, barley, buckwheat, pea. The realized work allows to determine tendencies of the economic efficiency of grain production, to estimate its competitiveness under conditions of the market environment.
\end{abstract}

Keywords: economic efficiency, economic-financial results, branch of grain crops, grain-forage crops, development tendency, market conjuncture.

\section{Introduction}

The effective economy is a necessary condition of activity of separate branches and enterprises altogether in the market environment. At the same time the achieved level of economic efficiency, especially of grain branch, has essential differences in the region, and separate crops are unprofitable. This all conditioned the necessity to realize the analysis of effectiveness of producing main grain crops, to reveal causes of its braking and development factors of their economy.

\section{Analysis of literary data and statement of the problem}

Problems of the grain subcomplex development, increase of the economic efficiency of production and competitiveness of grain in Ukraine are elucidated in scientific works of many scientists, especially, it is noted, that grain economy as a priority branch of AI determines its modern development and food safety of the country in whole, and the level of their use depends on production organization, its technologies and many other factors, including climate conditions [1-3]. Theoretical principles were grounded and practical recommendations as to increasing competitiveness of agricultural enterprises at the grain market were elaborated in $[4,5]$. The methodology of strategic prognostication was elaborated, the analysis of the development of agricultural production was realized and prognosticated indices until 2025 were calculated in [6]. Methodical principles and indices of the estimation of the competitiveness of the grain economy branch were also studied in $[7,8]$. Based on realized researches there were offered main internal and external directions of increasing the competitiveness level of grain that influences the strengthening of grain economy branch and enterprises, increase of export volumes and improvement of economic and social condition of our nation's life $[9,10]$. There were determined directions of increasing the effective- 
ness of grain production functioning. There was studied the influence of grains fruitfulness on the economic efficiency of the branch. It was proved, that the essential increase of grain production and improvement of its economic efficiency is the main task of the agrarian state policy [11]. The program "Ukrainian seed-2015" determined ways of grain production growth, elucidated technological, economic and normative-legal principles of solving the grain problem of the country [5].

It's worth noting that despite the essential contribution of scientists in the solution of theoretical and practical tasks of the grain-food subcomplex stable development, this sector of agrarian economy still far from its potential possibilities. It is proved by the low level of fruitfulness of grain crops and their profitability, connected with a retrograde production technology, low productivity of labor in branches, unstable price policy at the market, unsatisfactory state of filling and using of state grain resources, periodical administrative prohibitions of grain export and so on.

The problem of the effective functioning of the grain branch at the region level is insufficiently studied that needs a deep and multi-aspect scientific grounding for the practical use. Just these regional problems have conditioned the topicality and choice of the research theme under concrete conditions of the market environment.

\section{Aim and tasks of research}

The main aim of the work is the analysis of the resource potential of the grain branch of the region.

The following tasks were set for attaining this aim:

1. To carry out the analysis of main production-economic indices.

2. To investigate the influence of factors on the branch efficiency under conditions of the market environment.

3. To reveal development tendencies of the grain branch of the region.

\section{Materials and methods of researches}

The scientific article includes data of statistical yearbooks, statistical collections of Ternopil region and Ternopil district. The methods, used in this work, are monographic, economic-statistical ones (statistical observation, grouping, comparison, determination of mean and relative values, indices), analysis and synthesis, calculative-constructive, abstract-logic.

\section{Results of researches}

The dynamics of results of economic-financial activity and their indices of realization of grain and leguminous crops at agricultural enterprises of Ternopil region are presented in Table $\mathbf{1 .}$

As it can be seen from the table during the analyzed period, there was revealed a distinct tendency to the increase of volumes of grain production and sale. Thus, the volume of grain for 100 ha of the harvested area increased from 2900 cen in 2010 to 6120 cen in 2014 or in 2,1 times and 5810 cen in 2016 or in 2 times. The analogous tendency was revealed also in grain sale. If in 2010 there was sold 2137 cen of grain for 100 ha of the harvested area, in $2014-4621$ cen that is 2,2 times more, and in 2016 - 3952, or 1,8 times more.

Grain sale marketability grew in the analyzed period. Thus, for example, the level of marketability in 2010 was $73,7 \%$, and in $2014-75,5 \%$. The increase of sale volumes, increase of the marketability level and increase of prices of realization of grain and leguminous crops favored the growth of the pure income. Thus the pure income volume of grain realization for 100 ha of the harvested area increased from 239,3 thousands hrn in 2010 to 808,1 thousands hrn in 2014 or in 3,4 times and to 1255,9 thousands hrn in 2016 or in 5,2 times. Such essential increase of the pure income volume was favored by the following factors: the increase of grains fruitfulness by improving natural-climate conditions of crops cultivation; the increase of grains realization volume; the market conjuncture and growth of prices for realized products. It is important that during 2010-2016 the mean price of realization of 1 cen of grain increased from 112,0 hrn to 317,79 hrn or in 2,8 times and the full cost of 1 cen of sold grain increased, correspondingly, from 99,54 hrn to $218,04 \mathrm{hrn}$, or - in 2,2 times. 
Table 1

Economic-financial results of realization of grain and leguminous crops at agricultural enterprises of Ternopil region $[12,13]$

\begin{tabular}{lccccccc}
\hline \multicolumn{1}{c}{ Parameters } & $\mathbf{2 0 1 0}$ & $\mathbf{2 0 1 1}$ & $\mathbf{2 0 1 2}$ & $\mathbf{2 0 1 3}$ & $\mathbf{2 0 1 4}$ & $\mathbf{2 0 1 5}$ & $\mathbf{2 0 1 6}$ \\
\hline Number of enterprises, units & 265 & 269 & 254 & 270 & 275 & 259 & 256 \\
Average area of tillage for an enterprise, ha & 1678 & 1696 & 1817 & 1754 & 1711 & 1699 & 1706 \\
\hline & For 100 ha of the harvested area & & & & \\
\hline & 2900 & 4400 & 4640 & 5071 & 6120 & 5499 & 5810 \\
\hline Produced grain, cen & 2137 & 2775 & 3592 & 2785 & 4621 & 2430 & 3952 \\
Sold grain, cen & 239,3 & 388,0 & 542,6 & 517,6 & 808,1 & 653,6 & 1255,9 \\
Pure income (proceeds), thousands hrn & 99,54 & 115,77 & 127,77 & 122,73 & 137,48 & 188,88 & 218,04 \\
Full cost of 1 cen of realized grain, hrn & 112,00 & 139,82 & 151,05 & 126,76 & 174,89 & 269,03 & 317,79 \\
Price of 1 cen of realized grain, hrn & \multicolumn{7}{c}{ Profit, hrn } \\
\hline
\end{tabular}

Let's note, that grain production and sale have the essential differentiation of economic-financial indices for grain crops varieties by years (Table 2).

Table 2

Economic-financial results of wheat realization at agrarian enterprises of Ternopil region [12, 13]

\begin{tabular}{|c|c|c|c|c|c|c|c|}
\hline \multirow{2}{*}{ Parameters } & \multicolumn{7}{|c|}{ Years } \\
\hline & 2010 & 2011 & 2012 & 2013 & 2014 & 2015 & 2016 \\
\hline Average harvested area, for an enterprise, ha & 669 & 627 & 714 & 527 & 505 & 554 & 625 \\
\hline Part of wheat area in tillage, $\%$ & 39,9 & 37,0 & 39,3 & 30,0 & 29,5 & 32,6 & 36,6 \\
\hline Costs, spent for 1 ha of theharvested wheat area, hrn & 1859 & 3244 & 4158 & 4110 & 8035 & 7588 & 9799 \\
\hline Wheat fruitfulness, cen/ha & 25,6 & 40,0 & 37,8 & 34,8 & 52,8 & 53,2 & 53,1 \\
\hline \multicolumn{8}{|c|}{ For 100 ha of the harvested area } \\
\hline Sold grain, c en & 1836 & 2487 & 3126 & 2775 & 3544 & 4078 & 3763 \\
\hline Pure income (proceeds), thousands hrn & 190 & 347 & 459 & 383 & 597 & 10260 & 11314 \\
\hline Full cost of 1 cen of realized wheat, hrn & 101,22 & 130,42 & 132,99 & 148,11 & 152,18 & 186,57 & 218,73 \\
\hline Price of $1 \mathrm{c}$ of realized grain, hrn & 103,38 & 139,59 & 146,80 & 137,85 & 168,39 & 251,58 & 300,67 \\
\hline \multicolumn{8}{|c|}{ Profit (loss), hrn } \\
\hline For 1 cen of sold wheat & 2,16 & 9,17 & 13,81 & $-10,26$ & 16,21 & 65,01 & 81,94 \\
\hline For 1 ha of the harvested area & 39,7 & 228,1 & 431,7 & $-284,7$ & 574,5 & 2651 & 3083 \\
\hline Coefficient of wheat income, point & 1,02 & 1,07 & 1,10 & 0,93 & 1,11 & 1,35 & 1,37 \\
\hline Wheat profitability, \% & 2,1 & 7,0 & 10,4 & $-6,9$ & 10,6 & 34,8 & 37,5 \\
\hline
\end{tabular}

As we can see on Table 2, wheat fruitfulness is closely connected with costs volumes for 1 ha of the harvested area of wheat. Thus, for example, in 2010 wheat fruitfulness was 25,6 cen/ha at costs $1859 \mathrm{hrn}$ for 1 ha of the harvested area, and in 2014 these indices were 52,8 cen/ha and $8035 \mathrm{hrn} / \mathrm{ha}$, respectively, and in 2016 - 53,1 cen/ha and $9799 \mathrm{hrn} / \mathrm{ha}$.

The analyzed period demonstrated a tendency of the intensification of wheat grain production, improvement of economic-financial results of the branch. Thus, for example, the volume of grain sale in the calculation for 100 ha of the harvested area increased from 1836 cen in 2010 to 3544 cen in 2014, or in 1,9 times, and to 4078 cen in 2015 - in 2,2 times. The pure income (proceeds) from wheat grain realization for this period increased, correspondingly, from 190 thousands hrn to 597 thousands hrn, and in 2015 - to 10260 thousands hrn and in 2016 - to 11314 thousands hrn for 100 ha of the harvested area of wheat. 
The profit mass in the calculation for both 1 cen of grain and 1 ha of the harvested area essentially increased in the analyzed period. For example, if in 2010 in the calculation for 1 cen of grain and for 1 ha of the harvested area there were received 2,16 hrn and 39,7 hrn, respectively, in 2014 these indices were 16,21 hrn and 574,5 hrn, respectively, and in 2016 these indices essentially increased.

The coefficient of marketability (pure income and costs ratio) in the analyzed period increased, correspondingly, from 1,02 to 1,37 points that is there was received by 35 kopecks more for 1 hryvnia, invested in the development of the region enterprise branch in 2016. So the financial results of wheat grain production essentially increased in the analyzed period.

It is worth noting, that the important place in the economy of the branch of grain and leguminous crops belongs to corn for grain (Table 3). As we can see on the table, last years the average harvested area of corn in the calculation for an agricultural enterprise of Ternopil region increased from 232 ha in 2010 to 496 ha in 2014 or in 2,1 times. The part of the harvested corn area increased in this period, correspondingly, from $13,8 \%$ to $29,0 \%$. At that costs, that is intensification level, increased in the calculation for 1 ha of the harvested corn area, correspondingly from $3503 \mathrm{hrn}$ (2010) to $8441 \mathrm{hrn}$ (2014), or in 2,4 times and to $11626 \mathrm{hrn}$ (2016), or in 3,3 times.

The researches demonstrated that the growth of the level of concentration and intensification of production favored: the increase of corn fruitfulness for the analyzed period, correspondingly, from $54,5 \mathrm{cen} /$ ha to $79,8 \mathrm{cen} /$ ha in average at enterprises of the region; the increase of grain realization for 100 ha of the harvested area and the pure income.

At that the part of the pure income, received from sale of corn grain in the total income of the grain branch, as it can be seen in Table 3, increased from 33,4 \% in 2010 to 56,4 \% in 2014 that testifies to the important role of corn grain in the development of economy of plant cultivation in particular and agrarian enterprises in general.

The analysis established, that corn grain production and sale at agricultural enterprises of the region has a positive tendency to the increase of both production and realization of products and to the improvement of economic-financial indices of the branch functioning.

Table 3

Economic-financial results of corn grain sale at enterprises of Ternopil region $[12,13]$

\begin{tabular}{|c|c|c|c|c|c|c|c|}
\hline \multirow{2}{*}{ Parameters } & \multicolumn{7}{|c|}{ Years } \\
\hline & 2010 & 2011 & 2012 & 2013 & 2014 & 2015 & 2016 \\
\hline Average harvested area for an enterprise, ha & 232 & 354 & 417 & 530 & 496 & 394 & 368 \\
\hline Part of corn area in tillage, $\%$ & 13,8 & 20,9 & 22,9 & 30,2 & 29,0 & 23,2 & 21,6 \\
\hline Costs, spent for 1 ha of the harvested area, hrn & 3503 & 4161 & 6518 & 6693 & 8441 & 9700 & 11626 \\
\hline Corn fruitfulness, cen/ha & 54,5 & 64,2 & 73,2 & 77,3 & 79,8 & 65,9 & 77,4 \\
\hline \multicolumn{8}{|c|}{ For 100 ha of the harvested area } \\
\hline Sold grain, cen & 3801 & 4258 & 5475 & 6294 & 6664 & 7467 & 4962 \\
\hline Pure income, thousands hrn & 450,8 & 560,1 & 798,1 & 669,3 & 1163,1 & 20089 & 16431 \\
\hline $\begin{array}{l}\text { Part of the pure income from corn sale in the } \\
\text { income of the grain branch, } \%\end{array}$ & 33,4 & 43,7 & 44,3 & 63,8 & 56,4 & 49,5 & 39,5 \\
\hline Full cost of 1 cen of sold corn grain, hrn & 92,17 & 97,71 & 119,06 & 106,35 & 126,68 & 188,88 & 205,24 \\
\hline Price of 1 cen of sold grain, hrn & 118,60 & 131,55 & 145,79 & 115,92 & 174,54 & 269,03 & 331,14 \\
\hline \multicolumn{8}{|c|}{ Profit (loss), hrn } \\
\hline For 1 cen of sold corn & 26,43 & 33,84 & 26,73 & 9,57 & 47,86 & 80,15 & 125,9 \\
\hline For 1 ha of the harvested area & 1005 & 1441 & 1464 & 602 & 3189 & 5985 & 6247 \\
\hline Income coefficient, point & 1,29 & 1,35 & 1,22 & 1,09 & 1,38 & 1,42 & 1,61 \\
\hline Corn profitability, $\%$ & 28,7 & 34,6 & 22,4 & 9,0 & 37,8 & 42,4 & 61,3 \\
\hline
\end{tabular}

The favorable conjuncture of corn grain at the agrarian market that is the growth of demand for grain and increase of its supply conditioned the proactive growth of prices comparing with prime cost. Thus, for example during 2010-2016 the full cost of 1 cen of corn grain increased, correspondingly from $92,17 \mathrm{hrn}$ to $205,24 \mathrm{hrn}$ or in 2,2 times and the price of realization of 1 cen 
of products in this period increased from $118,60 \mathrm{hrn}$ to $331,14 \mathrm{hrn}$ or in 2,8 time. All that favored the increase of profit volumes of both 1 cen of realized products and 1 ha of the harvested area. For example, the profit mass during 2010-2016 in the calculation for 1 cen of realized corn grain and $1 \mathrm{ha}$ of the harvested area increased, correspondingly from 26,43 hrn and $1005 \mathrm{hrn}$ to $125,9 \mathrm{hrn}$ and $6247 \mathrm{hrn}$ or in 4,8 and 6,2. The coefficient of income and profitability of the branch also increased during this period.

The important place in the development of the grain economy of the region belongs to barley. The main economic-financial indices of this crop are presented in Table 4.

\section{Table 4}

Economic-financial results of barley sale at agrarian enterprises of Ternopil region $[12,13]$

\begin{tabular}{|c|c|c|c|c|c|c|c|}
\hline \multirow{2}{*}{ Parameters } & \multicolumn{7}{|c|}{ Years } \\
\hline & 2010 & 2011 & 2012 & 2013 & 2014 & 2015 & 2016 \\
\hline Average harvested area for an enterprise, ha & 243 & 174 & 207 & 168 & 199 & 188 & 218 \\
\hline Part of barley area in tillage, $\%$ & 14,5 & 10,3 & 11,4 & 9,6 & 11,6 & 11,0 & 12,8 \\
\hline Costs, spent for 1 ha of the harvested area of barley, hrn & 1946 & 2377 & 3545 & 3475 & 3776 & 7514 & 9554 \\
\hline Barley fruitfulness, cen/ha & 20,5 & 32,4 & 35,7 & 28,4 & 48,4 & 48,9 & 51,6 \\
\hline \multicolumn{8}{|c|}{ For 100 ha of the harvested area } \\
\hline Sold grain, cen & 1862 & 1970 & 2661 & 2182 & 3380 & 3804 & 3806 \\
\hline Pure income (proceeds). Thousands hrn & 1217 & 320 & 475 & 359 & 602 & 10534 & 11346 \\
\hline Full cost of 1 cen of sold barley, hrn & 104,52 & 120,69 & 133,24 & 159,26 & 140,98 & 197,96 & 217,86 \\
\hline Price of 1cen of sold barley, cost & 110,58 & 162,44 & 178,57 & 164,51 & 178,10 & 276,94 & 298,10 \\
\hline \multicolumn{8}{|c|}{ Profit (loss), hrn } \\
\hline For 1 cen of sold barley & 6,06 & 41,75 & 45,33 & 5,25 & 37,12 & 78,98 & 80,24 \\
\hline For 1 ha of the harvested area & 1123 & 822 & 1206 & 1145 & 1255 & 3004 & 3054 \\
\hline Income coefficient, point & 1,06 & 1,35 & 1,34 & 1,03 & 1,26 & 1,40 & 1,37 \\
\hline Barley profitability, \% & 5,8 & 34,6 & 34,0 & 3,3 & 26,3 & 39,9 & 36,8 \\
\hline
\end{tabular}

The analysis demonstrated that the average harvested area of barley in the calculation for an enterprise during 2010-2016 decreased, correspondingly, from 243 ha to 218 ha. For this period costs in the calculation for 1 ha of the harvested area increased, correspondingly, from 1946 hrn to $9554 \mathrm{hrn}$ that conditioned the increase of barley fruitfulness in 2,5 times. It favored the increase of sale volumes of barley and pure income in the calculation for 100 ha of the harvested area.

The studies demonstrated that during the analyzed period the full cost of sold 1 cen of barley increased in 2,1 times, and its price - correspondingly in 2,7 times, that is the price increased by proactive rates comparing with the full cost of grain. This positive tendency conditioned the growth of income and profitability of barley grain production and sale.

Such valuable crop as buckwheat has the important value for supplying the population with food.

It was established, that during 2010-2016 the harvested area of buckwheat at agricultural enterprises decreased, correspondingly, from 9,3 thousands ha to 6,8 thousands ha. If the harvested area of buckwheat in all categories of economies in 1990 was 16,5 thousands ha, and the gross harvest - 15,8 thousands t, in 2016 the analogous indices were correspondingly at the level 10,2 thousands ha and 10,5 thousands t, or decreased correspondingly by 6,3 thousands ha and 5,3 thousands $t$ of products.

It must be underlined that buckwheat production decreased in all regions of Ukraine that led to the market conjuncture worsening, that is demand for buckwheat increased and supply decreased. Such tendencies don't satisfy our population's need in buckwheat at the expanse of own production and conditioned the essential growth of prices up to $45-55 \mathrm{hrn} / \mathrm{kg}$ in the net of retail trade.

Let's note, that buckwheat fruitfulness remains law that is the main factor that conditions the high prime cost of 1 cen of production, decelerates this crop development on the innovative base. Thus, for example, the average full cost of 1 cen of realized buckwheat increased during the analyzed period from $203,36 \mathrm{hrn}(2010)$ to $660,26 \mathrm{hrn}$ (2016) or in 3,2 times. 
The average price of 1 cen of sold buckwheat had essentially more fluctuations in this period. Thus, for example, if in 2010 the price of 1 cen of realized buckwheat was 376,01 hrn, in 2011 it was at the level $471,15 \mathrm{hrn}$ or by $95,14 \mathrm{hrn}$ more. The lowest price of 1 cen of buckwheat $(269,82 \mathrm{hrn})$ was in 2013 , and the highest - (1189,3 hrn $)$ - in 2016, the difference was more then 4,4 times. It is conditioned by the essential decrease of buckwheat supply at the agrarian market of the country. For example, in 2011 agrarian enterprises of Ternopil region sold 285 cen of buckwheat for 100 ha of the harvested area that is by $43,5 \%$ less than in 2010 . The analogous situation with buckwheat sale happened again in 2015-2016 that also led to the essential growth of prices (766,50-1189,3 hrn/cen). Marketability of buckwheat sale remains low (in 2011 was only 31,1\%), that conditions the swift growth of demand and increase of realization prices on this base. Such low level of marketability of buckwheat sale testifies to the fact that agrarian enterprises intentionally decrease supply of this product, creating the swift growth of demand and the growth of realization prices on this base. Such negative conjuncture as to demand and supply at the agrarian market gives grounds to think that it is necessary to strengthen the state regulation of products sale and the process of price formation for all types of products in Ukraine.

Such valuable food and forage crop as peas has the important value for the development of the grain economy branch. The main production-economic indices of this leguminous crop are presented in Table 5. As it can be seen from the table, the harvested area of pea had essential fluctuation during 2010-2015.

\section{Table 5}

Economic-financial results of peas sale at agrarian enterprises of Ternopil region $[12,13]$

\begin{tabular}{|c|c|c|c|c|c|c|c|}
\hline \multirow{2}{*}{ Parameters } & \multicolumn{7}{|c|}{ Year } \\
\hline & 2010 & 2011 & 2012 & 2013 & 2014 & 2015 & 2016 \\
\hline Harvested area of pea: totally, thousands ha & 5,3 & 2,2 & 2,6 & 2,4 & 6,8 & 6,9 & 9,1 \\
\hline In average for an enterprise, ha & 20,0 & 8,2 & 10,2 & 8,9 & 24,7 & 26,6 & 35,5 \\
\hline Cost, spent for 1 ha of the harvested area of pea, hrn & 1209 & 1911 & 2561 & 2759 & 3428 & 7514 & 10434 \\
\hline Pea fruitfulness, cen/ha & 16,3 & 22,9 & 31,0 & 26,4 & 34,5 & 34,7 & 37,9 \\
\hline \multicolumn{8}{|c|}{ For 100 ha of harvested area, cen } \\
\hline Produced pea & 1632 & 2286 & 3077 & 2635 & 3456 & 3465 & 3791 \\
\hline Sold pea & 962 & 1055 & 1404 & 1404 & 1504 & 1741 & 1631 \\
\hline \multicolumn{8}{|c|}{ For one person, kg } \\
\hline Produced pea & 8,0 & 7,4 & 7,4 & 5,9 & 22,0 & 22,4 & 32,1 \\
\hline Sold pea & 4,7 & 2,1 & 3,4 & 3,1 & 9,6 & 11,3 & 27,3 \\
\hline Full cost of 1 cen of sold pea, hrn & 125,67 & 181,12 & 182,31 & 196,40 & 227,89 & 288,21 & 343,48 \\
\hline Price of 1 cen of sold pea, hrn & 179,81 & 226,84 & 235,74 & 288,03 & 317,45 & 521,43 & 543,79 \\
\hline \multicolumn{8}{|c|}{ Profit (loss), hrn } \\
\hline For 1 cen of sold pea & 54,14 & 45,72 & 53,43 & 91,63 & 89,56 & 233,22 & 200,26 \\
\hline For 1 ha of the harvested area & 521 & 482 & 720 & 1287 & 1347 & 4060 & 3266 \\
\hline Income coefficient, point & 1,43 & 1,25 & 1,29 & 1,47 & 1,39 & 1,81 & 1,58 \\
\hline Pea profitability, \% & 43,1 & 25,3 & 29,3 & 46,7 & 39,3 & 80,9 & 58,3 \\
\hline
\end{tabular}

Thus, for example, in 2010 the harvested area of pea at enterprises of the region was 5,2 thousands ha, and during 2011-2013 it decreased to 2,2-2,4 thousands ha, or in 2,4-2,2 times comparing with 2010. The harvested area of pea increased again up to 6,8 thousands ha in 2014 , in 2015 - to 6,9 thousands ha and to 9,1 thousands ha in 2016. It is a positive tendency, taking into account the fact that pea is a good forerunner for wheat and other ear crops.

At the same time the indicated harvested area was small and in 8,8 times less than in 1990 at agrarian enterprises (59,8 thousands ha) of Ternopil region.

The essential growth of costs in the calculation for 1 ha of the harvested area must be considered as positive. Thus, if in 2010 in the calculation for 1 ha of the harvested area $1209 \mathrm{hrn}$ were spent, in 2014 this index increased to $3428 \mathrm{hrn}$, and in 2016 - to $10434 \mathrm{hrn} / \mathrm{ha}$ or in 2,8-8,6 times. It positively influenced the development of this subbranch, especially: pea fruitfulness was in- 
creased correspondingly from $16,3 \mathrm{cen} /$ ha to $37,9 \mathrm{cen} / \mathrm{ha}$; volumes of pea production and sale were increased; economic indices of production and sale were improved.

The analysis demonstrated that the level of full cost and price of 1 cen of realized pea increased almost proportionally in the analyzed period. Thus, for example, during 2010-2016 the full cost of 1 cen of realized pea increased, as it can be seen from Table 5, correspondingly, from 125,67 hrn to $343,48 \mathrm{hrn}$, or in 2,7 times, and the price of sale increased during this period - from 179,81 hrn to $543,74 \mathrm{hrn}$, or in 3 times. At such levels of pea cost and price of its realization the profit mass in the calculation for 1 cen of product increased. Thus, for example, enterprises of Ternopil region received the profit from 1 cen of sold pea in 2010 - 54,14, in 2014 - 89,56 hrn, in 2015 - 233,22 hrn and in $2016-200,26 \mathrm{hrn}$. The essentially more profit was received in the analyzed period in the calculation for 1 ha of the harvested area. Thus, if in 2010 in the calculation for 1 ha of the harvested area regional enterprises received 520,8 hrn, in $2014-1347,0 \mathrm{hrn}$, in $2015-4060 \mathrm{hrn}$, in $2016-3266 \mathrm{hrn}$. Such essential increase of profit for 1 ha of the harvested area of pea is mainly conditioned by two factors, namely: the increase of volumes of product sale; the increase of the price of product realization.

Let's note, that the favorable market conjuncture at the correspondent level of cost and sale prices created proper conditions for leguminous crops subbranch functioning.

\section{Discussion of results}

The researches of the economic efficiency of production of grain of main food and grain-forage crops at agricultural enterprises of Ternopil region for 2010-2016 gave a possibility to reveal the dynamics of positive changes in the development of grain branch, especially:

- it was established, that enterprises of Ternopil region have favorable natural-climatic conditions for cultivating all food and grain-forage crops;

- volumes of costs for 1 ha of the harvested area (intensification level) was increased for all crops that is the one of main factors of the increase of their fruitfulness and economic efficiency of grain production;

- sowing areas for grain crops were increased that gave a possibility to raise volumes of production and sale of grain as the one of main factors of the pure income growth - own source of replenishment of costs for productive needs of enterprises;

- there was revealed the favorable grain market conjuncture and proportions of the growth of prime cost and prices of sale of 1 unit of products that had a positive influence on the improvement of financial results of both separate crops and grain branch in whole;

- it was established, that volumes of grain sale, its full cost and price are the main factors of formation of the profit mass at an enterprise and in the branch in whole.

In the process of the research we revealed the braking factors of the grain branch development, especially:

- the low level of material-technical support (capital/labor ratio) of enterprises. Available tractors, combines and other technical means are morally archaic and physically deteriorated, their number is not enough that results in a disorders of the production technology and losses of ready products;

- the part of the harvested area of grain and leguminous crops in the structure of sowing areas is increased that negatively influences the effectiveness of agrarian lands use (diseases of plants, vermin, wild grass increase) in future;

- the essential differentiation takes place in fruitfulness levels of crops, economic results of the branch that testifies to present reserves of the economic growth;

- the swift growth of the level of prime cost and prices of realized products are conditioned by inflation of the national economy that resulted in the growth of prices for food products and decrease of the purchasing ability of Ukrainian population.

The realized researches gave a possibility to reveal the modern tendencies of the grain economy development and became a base of a further research, especially:

- improvement of the level of material-technical support of needs of agrarian enterprises bases of introduction of innovative-resource-saving technologies of grain production and sale;

- grounding of the rational branch structure of the grain economy at enterprises of the studied region taking into account satisfaction of internal needs of food and its export; 
- realization of regressive factor analysis of full cost of realized grain (wheat) and prognostication of the main parameters of the branch development in the competitive environment;

- improvement of the state regulation of processes of realization of products, especially food grain at regional markets, price formation, activation of the innovative-investment development of enterprises.

The realized researches will be useful for the practical activity of agrarian enterprises for raising the economic efficiency of the functioning of components of the own grain economy, growth of competitiveness of grain of main food and grain-forage crops at the internal and external markets.

\section{Conclusions}

The article presents the analysis of the dynamics of the economic efficiency of production of grain of main food and grain-forage crops of the region that gives a possibility to make the following conclusions:

1. There was revealed the positive dynamics of the production-economic indices, namely: fruitfulness of all grain and leguminous crops was essentially increased; volumes of grain realization, pure income, profit and coefficient of the branch income were increased that is a base of the stable development of agrarian enterprises by the principle of expanded reproduction.

2. There was established the intensive influence of external and internal factors complex on the economic efficiency of the grain branch. It is necessary to consider as internal ones: costs for 1 ha of the harvested area (intensification level); volume of products sale; full cost of 1 cen of realized grain; price of realization of 1 cen of realized grain. The external ones are the state support and favoring of the innovative-investment development of agrarian business; regulation of production and sale of grain products, price formation and increase of grain competitiveness.

3. There were revealed the tendencies of the excessive increase of the part of harvested areas of wheat, corn for grain, barley and decrease of areas for rye, buckwheat, pea in the structure of tillage of enterprises that results in disorders of agrotechnical requirements (crops rotation, bad grass, diseases) of production and decrease of agrarian lands productivity.

\section{References}

[1] Andrijchuk, V. G. (2006). Efektyvnist diyalnosti agrarnyh pidpryyemstv: teoriya, metodyka, analiz. Kyiv: KNEU, 292.

[2] Bojko, V. I. (2007). Zerno i rynok. Kyiv: NNCz IAE, 312.

[3] Shpychak, O. M., Voskobijnyk, Yu. P., Shpykulyak, O. G. (2013). Vytraty ta efektyvnist vyrobnycztva produkciyi v silskogospodarskyh pidpryyemstvah. Kyiv: NNCz IAE, 440.

[4] Maznyev, G. Ye. (2011). Ekonomichna efektyvnist innovacijnyh tehniko - tehnologichnyh rishen v agrarnomu vyrobnycztvi. Ekonomika APK, 6, 118-127.

[5] Olijnyk, V. (2010). Sobivartist zerna yak chynnyk formuvannya jogo konkurentospromozhnosti. Visnyk HNAU, 6, 354-359.

[6] Lupenko, Yu. O. (2012). Strategichni napryamy rozvytku silskogo gospodarstva Ukrayiny na period do 2020 r. Kyiv: IAE, 182.

[7] Parxomecz, M. K., Gudak, V. V. (2014). Organizacijno-ekonomichnyj mehanizm zabezpechennya dohidnosti silskogospodarskyh pidpryyemstv regionu: teoriya, metodyka, praktyka. Ternopil: TNEU, 256.

[8] Parhomecz, M. K., Solovej, I. S. (2015). Metodychni zasady ta pokaznyky ocinky rivnya konkurentospromozhnosti galuzi zernovogo gospodarstva regionu. Innovacijna ekonomika, 3, 128-143.

[9] Parhomecz, M. K., Uniyat, L. M., Solovej, I. S. (2017). Ocinka konkurentospromozhnosti zerna ta napryamy yiyi pidvyshhennya u pidpryyemstvah. Ukrayinskyj zhurnal prykladnoyi ekonomiky, 2, (1), 85-95.

[10] Programa "Zerno Ukrayiny - 2015" (2011). Kyiv: DIA, 48.

[11] Hrystenko, G. M. (2013). Rozvytok ta napryamy pidvyshhennya efektyvnosti zernovoyi galuzi. Visnyk NTU «HPI», 53(1026). 182-188.

[12] Derzhavna sluzhba statystyky Ukrayiny. Golovne upravlinnya statystyky u Ternopilskij oblasti. Silske gospodarstvo Ternopilskoyi oblasti za 2010-2015 rr. Ternopil: 228.

[13] Osnovni ekonomichni pokaznyky roboty silskogospodarskyh pidpryyemstv Ternopilskoyi oblasti za 2011-2015 rr. (2017). Ternopil, Golovne upravlinnya statystyky u Ternopilskij oblasti, 69. 